\title{
SUPPRESSION OF BACTERIAL WILT DISEASE \\ BY SOME MARINE MACROALGAL EXTRACTS ISOLATED FROM SAFAGA COAST OF RED SEA, EGYPT
}

\author{
SEHAM M. HAMED ${ }^{1}$ and NEVEIN A.S. MESSIHA ${ }^{2 *}$
}

1. Soil Microbiology Department Soils, Water and Environment Research Institute, ARC, Giza, Egypt.

2. Bacterial Plant Disease Department, Plant Pathology Research Institute, Agricultural Research Center, Cairo, Egypt .

*nevein messiha@yahoo.com

(Manuscript received 15 August 2018)

\begin{abstract}
$\mathrm{M}$ arine macroalgae are an excellent source of biologically active compounds. Among tested 8 different marine macroalgal species, we intensively studied the antibacterial activity of the methanol extract of four selected algal species; U/va lactuca, Caulerpa racemosa, Acanthophora spicifera and Sargassum dentifolium against Ralstonia solanacearum, the causal agent of bacterial wilt. In vitro assay showed that $U$. lactuca had the highest antibacterial activity while Sargassum dentifolium showed the lowest effect. In contrast, $A$. spicifera extract was the most disease suppressive in the in vivo study. The suppressive effects of extracts were generally low in sandy soil compared to clay one. The interrelation between growth inhibition of $R$. solanacearum, wilt suppression and phenolic constitutions in algal extracts were investigated. Results showed that gallic and coumaric acids were correlated with inhibition of the pathogen in vitro while hydrxybenzoic, chlorogenic, vanillic, salicylic and ferulic aids were in vivo correlated with disease suppression under greenhouse conditions. Use of algal extracts, as a strong antibacterial and antioxidant, can be employed as a part of an integrated program for controlling of plant diseases. Further investigations are needed on the feasibility of application.
\end{abstract}

\section{INTRODUCTION}

Potato brown rot (bacterial wilt) is a serious disease with global economic impacts. The pathogen survives in drainage water for almost 4 months under optimum conditions (Stevens et al., 2018). It survives in plant debris, alternative weed hosts such as, Portulaca oleracea, Rumex dentatus, Solanum nigrum and volunteer potato plants (Farag et al., 2004).

The most important aspects applied to control the disease are avoidance of invasion by the pathogen from old to new areas and protection of the constructed pest free areas (PFAs), through avoidance of disease introduction. Many management regimes were employed with variable degrees of success including, different fertilization regimes (Messiha et al., 2007a), antioxidants (Farag et al., 2017), and cyanobacteria 
(Mikhail et al., 2016). Use of biocontrol agent (Elhalag et al., 2016) as well as biological soil disinfestations (BSD) (Messiha et al., 2007b) and solarization (Schönfeld et al., 2003) are other non-chemical means to control the disease.

The use of algal products from marine macroalgae as an important source of phenolic compounds was investigated (Mišurcován, 2011). Marine macroalgae were proven to contain active biocontrol agents which can be used successfully in controlling many soil borne pathogens as well as improving plant growth (Ibraheem et al., 2017). Seaweed extract (SWE) is known for its antioxidant properties (Matanjun et al., 2008) as well as a promising source of phytohormones as cytokinins, auxins, polyamines and betaines (Zhang et al., 2003). Cytokinins are considered as antioxidants which inhibit the activity of free radical groups that are responsible for chlorophyll degradation, (Yan, 1993).

Seaweed extract (SWE) was proven to suppress Ralstonia solanacearum, increase nutrient uptake and improve crop productivity (Farag et al., 2017). Increasing nutrient uptake would reduce the required nitrogen fertilization (Majeed et al., 2017). The antibacterial potential of SWE is correlated by Zhang et al., (2006) to the high content of polyphenol.

The aim of this study was to evaluate some marine macroalgal extract as a new environment friendly approach that would be integrated into program for controlling potato brown rot.

\section{MATERIALS AND METHODS}

\section{Algal material collection}

Ulva lactuca Linnaeus and Caulerpa racemosa (Chlorophyta), Sargassum virgatum, Sargassum dentifolium Grunow, Sargassum latifolium, Padina gymnospora (kütz) vichers, Hydroclathrus clathratus (Phaeophyta), and Acanthophora spicifera Vahl (Rhodophyta) were collected from the coast of the Red sea, Safaga district, Egypt, located at $26^{\circ} 44^{\prime} \mathrm{N}$ and $33^{\circ} 56^{\prime} \mathrm{E}$. The algal samples (fresh samples with variable mass and volume) were washed with tap water to remove adhered epiphytes and associated debris as much as possible, then were cleaned using a brush with $5 \%$ ethanol to remove the adhering microflora. The algal specimens were air dried under shade at room temperature and were grind thoroughly by electrical blender and sieved through 0.5 $\mathrm{mm}^{2}$ mesh sieve plate. The algal powder specimens were then soaked in methanol before use to estimate their antimicrobial activity.

\section{Preparation of algal extracts}

The extraction was made according to the method described by Hellio et al., (2001). Five hundred grams of dried algal powders were soaked in $3 \mathrm{~L}$ methanol 95\%, 
at room temperature for $72 \mathrm{~h}$. The collected algal extracts were then filtered through Whatman No.1 filter paper. The obtained filtrates were concentrated under reduced pressure in the rotatory evaporator (GG SENCO) to complete dryness. The dried crude extracts were stored at $4{ }^{\circ} \mathrm{C}$ for subsequent use.

\section{Isolation and identification of $\boldsymbol{R}$. solanacearum}

Within the activities of the national project entitled "Environmental friendly program for controlling potato brown rot" STDF2905, ten $R$. solanacearum isolates were isolated and purified from different habitats (soil, water and infected potato tubers) from different geographical locations. Wardan, (Giza) and Ganoub El-Tahrir (Behera), sandy soils and Talia (Minufiya), Sids (Beni-Suef), (clay soil).The isolated pathogen was cultured and monitored using modified SMSA selective medium agar plates (Anonymous, 1998). Typical colonies (irregular shape, diffuse slimy white with purple centers) were tested using Immunofluorescence Antibody Staining (IFAS) followed by pathogenecity test on transplanted tomato seedling (cv. Pinto) (Janse, 1988). The most severe isolate was selected for further work. Identification of the selected $R$. solanacearum isolate was confirmed by sequencing the 16S-rDNA gene using an 8capillary Genetic Analyzer (Applied Biosystem) at the Agricultural Research Center as described by (Farag et al., 2017).

\section{Effect of algal extracts on $R$. solanacearum growth in vitro}

The methanol extract of eight marine macro algae, were evaluated for their inhibitory effect against $R$. solanacearum.

The inoculum density of $R$. solanacearum was adjusted to $\left(\mathrm{OD}_{600}=0.3\right)$ by spectrophotometer (Jenway 6300, Essex, UK) to reach final concentration of $0.5 \times 10^{9}$ $\mathrm{CFU} / \mathrm{ml}$ and $0.5 \times 10^{8} \mathrm{CFU} / \mathrm{ml}$. One hundred $\mu \mathrm{l}$ was spread on the surface of SMSA media. Five wells of $0.5 \mathrm{~cm}$ diameter were made in each plate to be filled with each algal extract. Five plates were designated for each algal extract. Algal extract was dissolved in methanol at concentration of $10 \mathrm{mg} / \mathrm{ml}$. Each well was filled with $10,20,50$ or 100 $\mu \mathrm{l}$ from the extract with the negative controls being filled with the same volume of methanol only. The plates were incubated at $28^{\circ} \mathrm{C}$ for 3-7 days and inhibition zone was measured.

\section{Effect of algal extracts on bacterial wilt under greenhouse conditions}

Soil was collected from two areas with no history of potato brown rot infestation, Ismailia (light clay soil) and Nubaria (sandy soil). Soil samples were bacteriologically checked to ensure freedom of $R$. solanacearum. One hundred twenty pots (200 $\mathrm{cm}^{3}$ each) were filled with $250 \mathrm{~g}$ of either sandy soil or clay soil (equal number of pots). Two tomato seedlings were grown in each pot to ensure having at least one 
tomato seedling for each pot. Standardized suspension of the pathogen was mixed with the soil to achieve final concentration of the pathogen at $10^{7} \mathrm{CFU} / \mathrm{g}$. soil. Three leaved tomato seedlings were transplanted to the inoculated soil after being treated with the different algal extracts. Each seedling was immersed in water solution of powdered extract ( $25 \mathrm{mg}$ ) dissolved in $2.5 \mathrm{ml}$ water. The four algae selected were, $U$. lactuca, $C$. racemosa, $A$. spicifera and $S$. dentifolium. The experiment was carried under controlled conditions in the quarantine greenhouse at the Potato Brown Rot Project (PBRP) for 3 weeks. The conditions were adjusted to around $25^{\circ} \mathrm{C}$ during the day and $20^{\circ} \mathrm{C}$ at night with relative humidity (70-85\%) and photoperiod of 14 hours. The effect of four algal extract on potato wilt suppression was evaluated on tomato seedlings. The layout of the experiment is shown in table 1.

Table 1. Layout of the greenhouse experiment for evaluating of the effect of marine macroalgal extracts on potato brown rot suppression.

\begin{tabular}{|l|l|l|l|l|l|l|l|l|l|l|l|l|}
\hline Treatment & \multicolumn{2}{|l|}{ Negative control } & \multicolumn{2}{l|}{$\begin{array}{l}\text { Positive } \\
\text { control }\end{array}$} & \multicolumn{2}{l|}{ Ulva lactuca } & \multicolumn{2}{l|}{$\begin{array}{l}\text { Caulerpa } \\
\text { racemosa }\end{array}$} & \multicolumn{2}{|l|}{$\begin{array}{l}\text { Acanthophora } \\
\text { spicifera }\end{array}$} & \multicolumn{2}{l|}{$\begin{array}{l}\text { Sargassum } \\
\text { dentifolium }\end{array}$} \\
\hline & Clay & Sandy & clay & sandy & clay & sandy & clay & sandy & clay & sandy & clay & Sandy \\
\hline No. of pots & 10 & 10 & 10 & 10 & 10 & 10 & 10 & 10 & 10 & 10 & 10 & 10 \\
\hline
\end{tabular}

For negative and positive control the seedlings were immersed in water (instead of methanol to avoid phytotoxicity). Negative control, the soil was not inoculated with the pathogen.

Disease incidence was presented by measuring AUDPC (area under disease progress curve) and count of the pathogen in rhizosphre using SMSA media (Anonymous, 1998) and IFAS (Janse, 1988). AUDPC were calculated according to percentage of wilted leaves progress per each pot (plant) overtime (Winstead and Kelman, 1952 \& Messiha, 2006)

$$
\text { Disease index }(\%)=\left[\Sigma\left(n i \times v_{i}\right) \div(V \times N)\right] \times 100
$$

$n i=$ number of plants representing each disease rating; $v i=$ disease rating; $V=$ the highest disease rating (5); and $N=$ total number of plants. Disease rating was calculated as following scale: $1=$ no symptoms, $2=$ one-two leaves wilted, $3=$ most of leaves wilted, $4=$ all leaves wilted and $5=$ whole plant died. (Winstead and Kelman 1952)

\section{Determination of phenolic compounds in algal extracts}

Determination of phenolic compounds in algal extracts was made at Al-Azhar University (The Chromatographic analysis unit). Extraction of phenolic compounds from algae was made according to Machu et al., (2015). The phenolic compound content was determined using HPLC column (KROMASIL, $150 \times 4.6 \mathrm{~mm}$ ), with GBC (UV/vis) detector. Pump GBC LC 1110 pump. Analysis was made using win chromatography software (ver. 
1.3). The flow rate was $1 \mathrm{ml} / \mathrm{min}$. The detection was made at UV $280 \mathrm{~nm}$. Elution was made with (methanol: water: tetrahydrofuran: acetic acid), (23: 75: 1: 1)

\section{Statistical analysis}

One-way ANOVA was employed to test the significant difference between the inhibition zones of different algal extracts. NPar-test (Mann-Whitney test) was employed to test the difference in disease incidence between tomato treated with different algal extracts and non-treated control. Correlation analysis (1-tailed) was employed to correlate phenolic content of different algal extracts from one side, inhibition zone (in vitro) and disease incidence (in vivo) from the other side. The used software for different analysis was SPSS23.

\section{RESULTS}

\section{Isolation and identification of $\boldsymbol{R}$. solanacearum:}

The most aggressive $R$. solanacaerum isolate, according to its pathogenicity was that strain isolated from Talia, Minufiya governorate. The isolate showed $95 \%$ similarity with $R$. solanacearum, $R$. pickettii and $R$. syzygii according 16S-rDNA gene sequencing (Fig 1). Pathogenicity test confirmed that the recovered isolate was $R$. solanacearum.

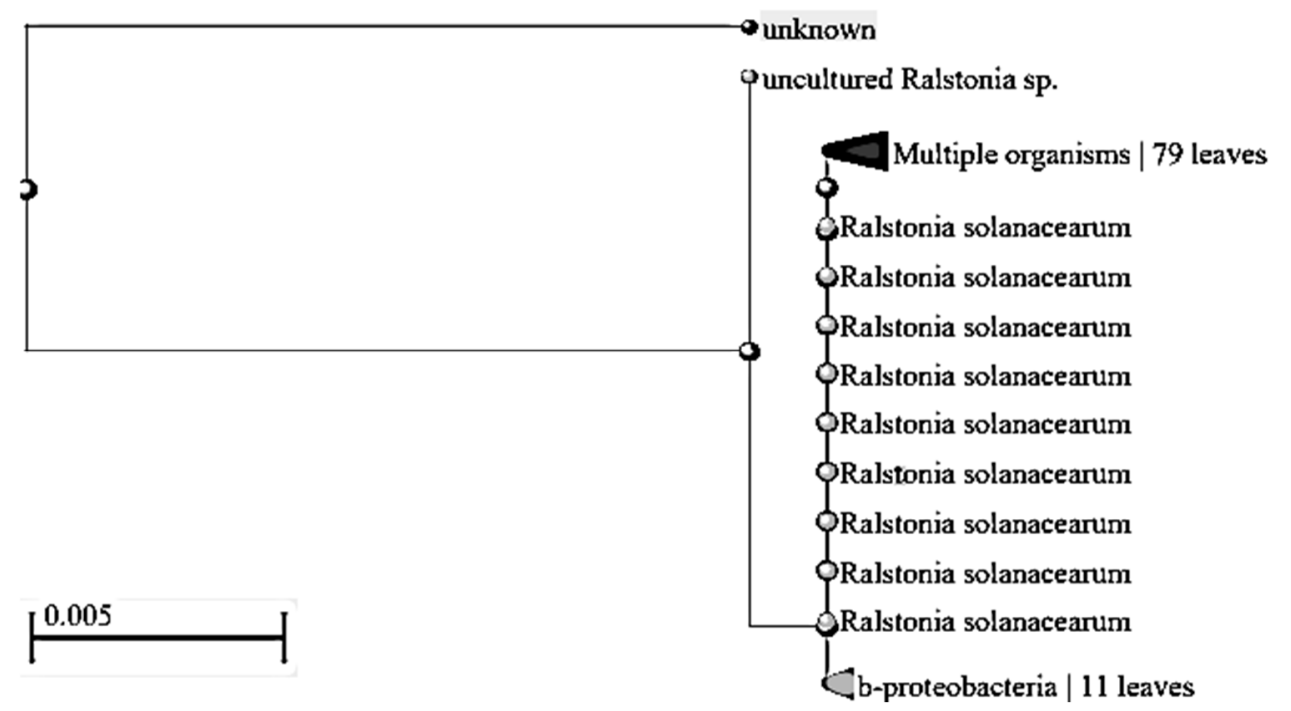

Fig. 1. Neighbor Joining Blast Tree of 16S rRNA database. The unknown refers the $R$. solanacearum isolated from Talia, Minufiya 


\section{Inhibitory potential of algal extracts on $R$. solanacearum in vitro}

In the present study, in vitro assay was conducted using methanol extracts of marine macroalgae against $R$. solanacearum, at two different concentrations of the pathogen $0.5 \times 10^{8} \mathrm{CFU} / \mathrm{ml}$ and $0.5 \times 10^{9} \mathrm{CFU} / \mathrm{ml}$ for $24 \mathrm{~h}$ of incubation on nutrient agar medium. Among the eight different marine macroalgal species, U. lactuca, $C$. racemosa, $A$. spicifera and $S$. dentifolium showed the highest antimicrobial activities. No inhibition zone was recorded for less than $0.5 \mathrm{mg}(50 \mathrm{\mu l})$ for all tested algal extracts. The effect was most clear at lower pathogen concentrations. Our results showed that, at low pathogen concentration $\left(0.5 \times 10^{8}, 24 \mathrm{~h}\right), U$. lactuca, C. racemosa and A. spicifera extracts showed comparatively greater inhibition activity by $(10 \pm 0.6 \mathrm{~mm}),(9 \pm 0.5 \mathrm{~mm})$ and $(8 \pm 1.0 \mathrm{~mm})$, however $S$. dentifolium showed the least inhibition zone by $(4 \pm 0.7$ $\mathrm{mm})(P<0.001)$. Meanwhile, at high pathogen concentrations $\left(0.5 \times 10^{9}, 24 \mathrm{~h}\right), U$. lactuca showed the highest significant inhibition zone by $(5 \pm 0 \mathrm{~mm})$ compared to $(4 \pm 0.4 \mathrm{~mm})$ by $C$. racemosa, $P=0.024,(3 \pm 0.6 \mathrm{~mm})$ by $A$. spicifera, $P=0.004$ and $(2 \pm 0.3 \mathrm{~mm})$ of $S$. dentifolium, $P<0.001$ (table 2).

Table 2. Inhibition zone associated with different algal extracts

\begin{tabular}{|l|c|c|}
\hline \multirow{2}{*}{ Algal extract } & \multicolumn{2}{|c|}{ Inhibition zone of $0.5 \mathrm{mg}$ algal extract in mm } \\
\cline { 2 - 3 } & $0.5 \times 10^{8} \mathrm{CFU} / \mathrm{ml} * *$ & $0.5 \times 10^{9} \mathrm{CFU} / \mathrm{ml}$ \\
\hline Ulva lactuca ${ }^{a}$ & $10 \pm 0.6^{2}$ & $5 \pm 0 * 3$ \\
Caulerpa racemosa ${ }^{b}$ & $9 \pm 0.5^{2}$ & $4 \pm 0.4^{4}$ \\
Acanthophora spicifera ${ }^{c}$ & & $3 \pm 0.6^{5}$ \\
Sargassum dentifolium ${ }^{d}$ & $8 \pm 1.0^{2}$ & $2 \pm 0.3^{6}$ \\
\hline
\end{tabular}

*average of 5 replicates (mean \pm SE)

**100 $\mu$ from the $R$. solanacearum inoculum density spread on the surface of the media

$1 \& 2 P<0.001$

$3 \& 4 P=0.024$

$3 \& 5 P=0.004$

$3 \& 6 P<0.001 \quad 4 \& 6 P=0.01$ 

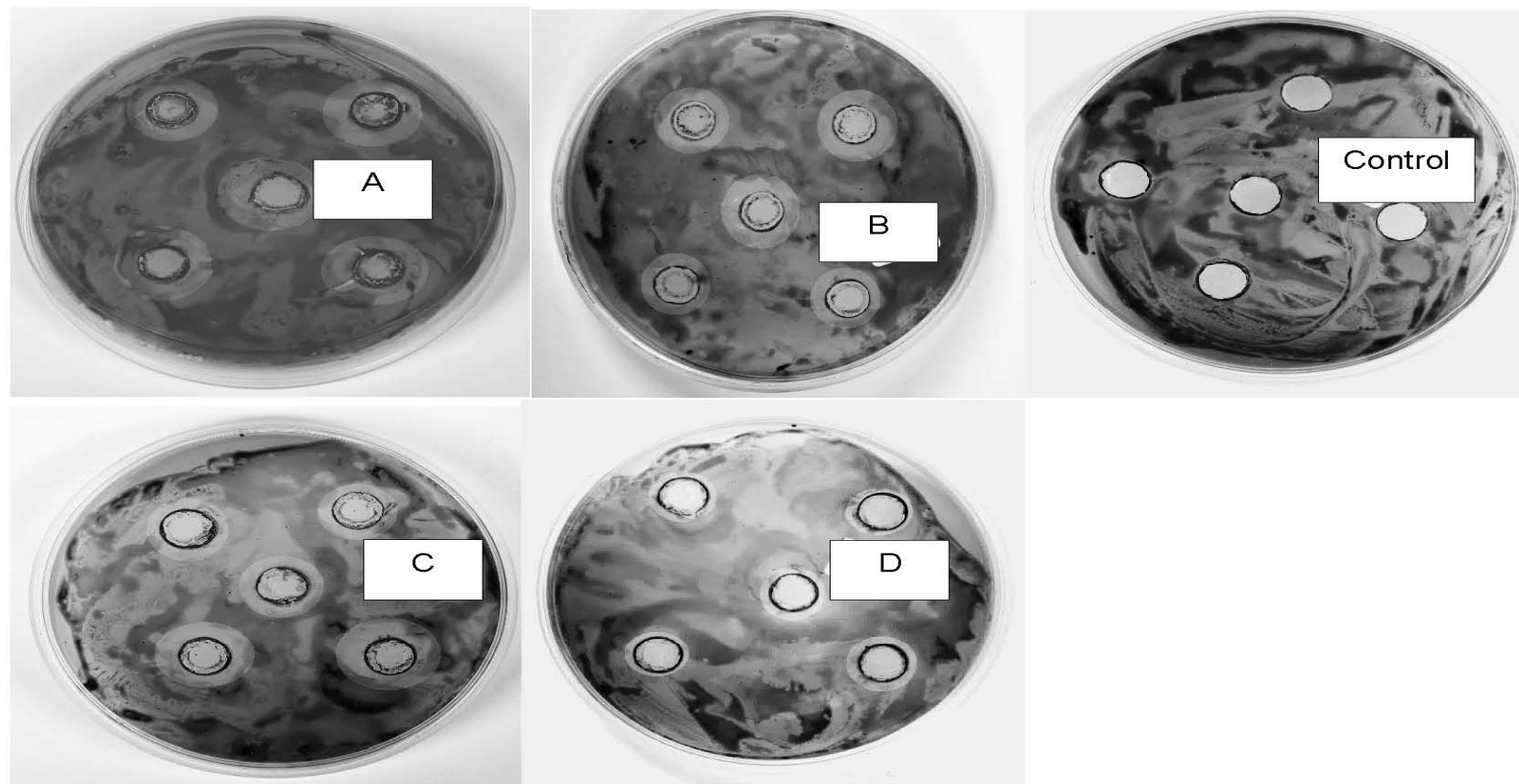

Fig. (2) Antimicrobial activity of the methanolic extract of: (A) U/va lactuca linnaeus C. Agardh Legolis, (B) Acanthophora spicifera, (C) Caulerpa racemose, (D) Sargassum dentifolium Grunow and Control (methanol only) against soil borne pathogenic bacteria $R$. solanacearum after $24 \mathrm{~h}$ of incubation. 


\section{Effect of algal extracts on bacterial wilt under greenhouse conditions}

The onset of symptoms was detected after 3 weeks and within 14 days wilted plants died, when the experiment was terminated. Healthy and dead plants were checked for the presence of the pathogen in plant tissues. In general, the disease incidence as expressed by wilt severity and AUDPC was more severe in sandy soil as compared to clay soil at $(P=0.007$ and 0.001$)$ for disease severity and AUDPC respectively (Table 3 and Fig 3 ).
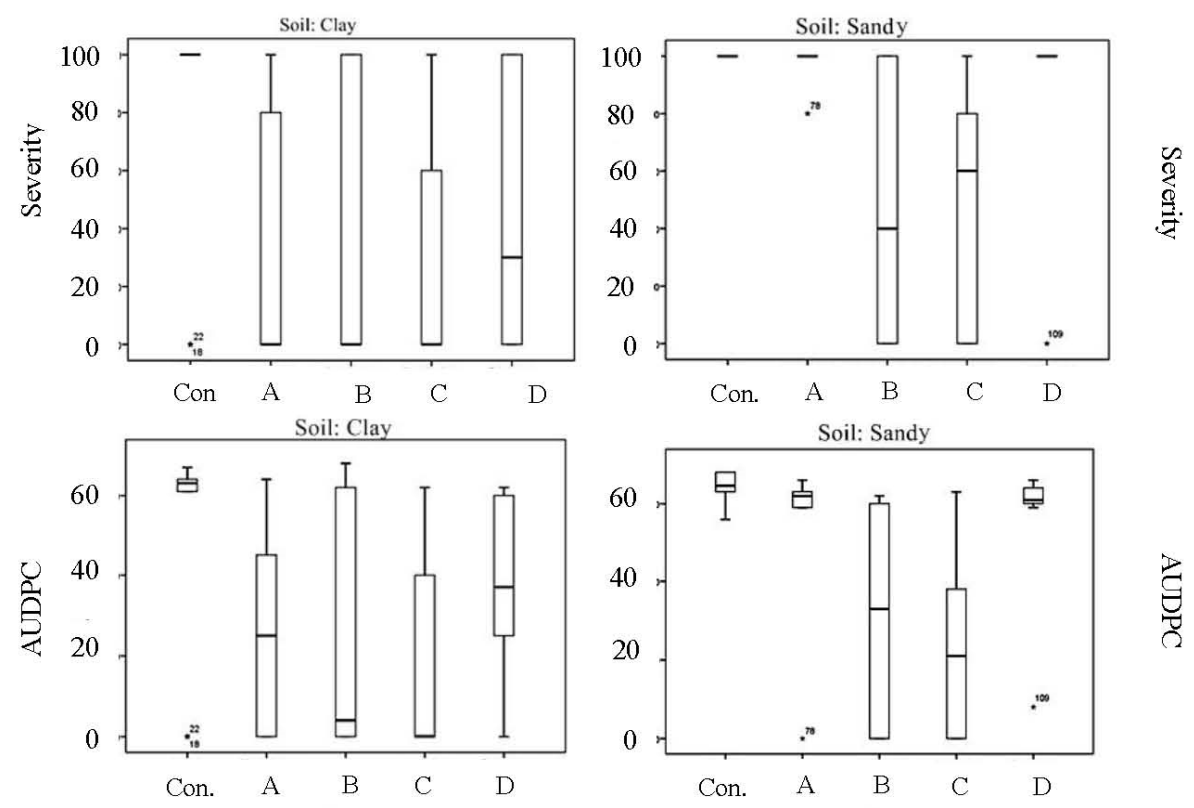

Fig. (3a) Effect of different algal extracts on disease severity and area under disease progress curve (AUDPC) under greenhouse conditions in two different soil types (clay and sandy)
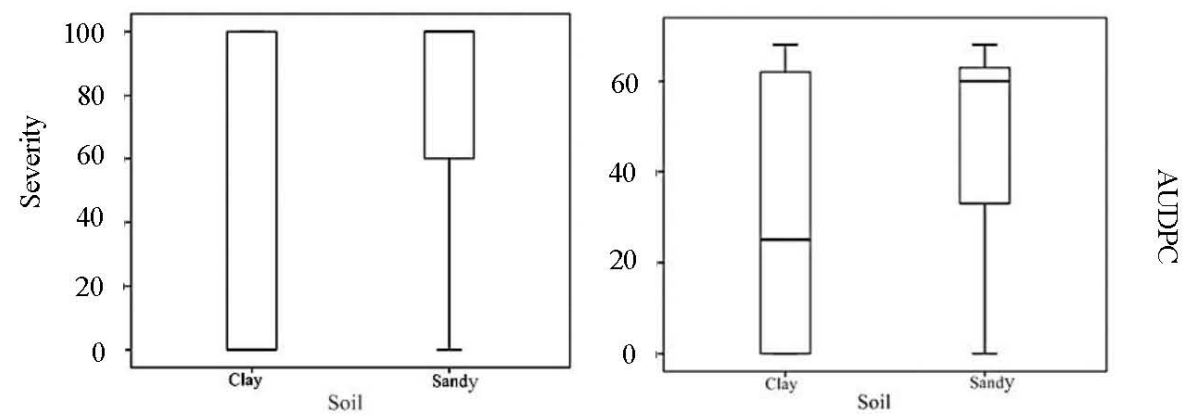

Fig. (3b) Effect of different soil types (clay versus sand) on disease incidence under greenhouse conditions.

(A) Ulva lactuca linnaeus C. Agardh Legolis, (B) Acanthophora spicifera, (C) Caulerpa racemose, (D) Sargassum dentifolium Grunow and (Con.) Control. 
U. lactuca showed significant decrease $65 \%(P=0.013)$ and $51 \%(P=0.053)$ in wilt severity and AUDPC respectively, in clay soil and was less effective in sandy soil showing only $13 \%(P=0.038)$ decrease in AUDPC. $C$. racemosa showed a trend of $50 \%$ decrease in wilt severity $(P=0.075)$ in clay soil and was more effective in sandy soil with $52 \%(P=0.005)$ and $51 \%(P=0.001)$ decrease in wilt severity and AUDPC respectively. A. spicifera was the most effective algal extract with $70 \%(P=0.006)$ and $(P=0.005)$ decrease in wilt severity and AUDPC in clay soil and $56 \%$ and $59 \%(P<0.001)$ decrease in sandy soil. $S$. dentifolium showed the least disease suppression with only $42.5 \%$ trend of decrease in wilt severity $(P=0.096)$ and significant $29 \%$ decrease in wilt severity $(P=0.022)$ in clay soil and was less effective in sandy soil with only $12 \%$ decrease in $\operatorname{AUDPC}(P=0.063)$.

\section{Determination of phenolic compounds in algal extracts}

Data in table (3) revealed that, $A$. spicifera showed the highest phenolic compound content $(176.067 \mu \mathrm{g} / \mathrm{gm})$, while $S$. dentifolium showed the lowest content $(124.129 \mu \mathrm{g} / \mathrm{gm})$. Interestingly, $A$. spicifera, had the highest components of hydroxybenzoic chlorogenic, vanillic, salicylic, ferulic and cinammic followed by $C$. racemosa. On the other hand, $U$. lactuca contained the highest content of gallic, resorcinol and coumaric acid.

Hydroxybenzoic acid showed significant negative correlation with disease incidence as expressed by AUDPC in clay soil, sandy soil as well as wilt severity in sandy soil $(-0.9, P=0.03)$, and $(-0.89, P=0.05)$ and $(-0.81, P=0.1)$ respectively. Similarly, chlorogenic acid showed significant negative correlation with disease incidence only in sandy soil, being $(-0.97, P=0.02)$ for wilt severity and $(-0.97, P=0.02)$ for AUDPC. Vanillic acid showed negative correlation with disease incidence $(-0.97, P=0.02)$ only in sandy soil. Salicylic acid showed negative correlation with wilt severity $(-0.84, P=0.08)$ and AUDPC $(-0.98, P=0.01)$ for clay soil and was less significant for wilt severity in sandy soil $(-0.79, P=0.1)$. Freulic acid showed significant negative correlation with disease incidence only in sandy soil, being $(-0.94, P=0.03)$ for wilt severity and $(-0.91$, $P=0.04$ ) for AUDPC.

Interestingly, gallic acid showed significant positive correlation with inhibition zone (antibacterial potential in vitro) with $(+0.79, P=0.1)$ at low inoculum density of the pathogen $\left(0.5 \times 10^{8} \mathrm{CFU}\right)$ and $(+0.84, P=0.08)$ at high inoculum density $\left(0.5 \times 10^{9}\right.$ CFU) (Table 3 ). Similarly, coumaric showed significant positive correlation with antibacterial potential in vitro by $(+0.9, P=0.07)$ at both low and high inoculums density of the pathogen. Resorcinol acid showed negligible ratio for different tested algal extracts (Table 3 ).

Hydroxybenzoic showed significant positive correlation with salicylic acid and Cinammic $(+0.98, P=0.01)$ and $(+0.9, P=0.05)$ respectively. Cinammic acid was 
represented by a considerably little amount in the different algal extracts and its correlation with disease suppression may related to a combined effect of hydroxybenzoic, salicylic and cinammic acid (Table 3). Chlorogenic acid showed positive correlation with vanillic and freulic acids being $(+0.996, P=0.002),(+0.82, P=0.09)$ respectively.

Table 3. Phenolic acid constitution of different algal extracts and effect on the pathogen and disease severity

\begin{tabular}{|c|c|c|c|c|c|}
\hline \multirow{2}{*}{$\begin{array}{l}\text { Phenolic acids } \\
\qquad(\mu g / g m)\end{array}$} & \multicolumn{4}{|c|}{ Algal strains } & \multirow{2}{*}{$\begin{array}{l}\text { Retention } \\
\text { Time } \\
\text { (min) }\end{array}$} \\
\hline & Ulva lactuca & $\begin{array}{l}\text { Caulerpa } \\
\text { racemosa }\end{array}$ & $\begin{array}{c}\text { Acanthophora } \\
\text { spicifera }\end{array}$ & $\begin{array}{l}\text { Sargassum } \\
\text { dentifolium }\end{array}$ & \\
\hline Hydrxybenzoic $^{\mathrm{a}}$ & 8.14 & 9.27 & 10.18 & 6.14 & 1.3 \\
\hline Gallic $^{b}$ & 41.42 & 30.55 & 33.71 & 27.22 & 2.1 \\
\hline Resorcinol $^{c}$ & 0.041 & 0.028 & 0.037 & 0.019 & 2.8 \\
\hline Chlorogenic $^{d}$ & 25.33 & 35.98 & 38.89 & 30.31 & 3.3 \\
\hline Vanillice & 6.66 & 10.66 & 12.53 & 7.97 & 4.1 \\
\hline Coumaric & 29.52 & 20.04 & 23.17 & 15.11 & 5 \\
\hline Salicylic ${ }^{9}$ & 19.12 & 19.55 & 22.15 & 13.82 & 5.9 \\
\hline Ferulich & 15.55 & 25.26 & 29.12 & 20.93 & 7.5 \\
\hline Cinammic' & 3.19 & 4.18 & 6.28 & 2.61 & 8 \\
\hline \multirow[t]{2}{*}{ Total } & 148.971 & 155.518 & 176.067 & 124.129 & \\
\hline & & & & & $\begin{array}{l}\text { Untreated } \\
\text { control (PC) }\end{array}$ \\
\hline $\begin{array}{l}\text { In vitro inhibition of } \boldsymbol{R} \text {. } \\
\text { solanacearum }\left(0.5 \times 10^{8}\right. \\
\mathrm{CFU} / \mathrm{ml}) * 1\end{array}$ & $10 \pm 0.6$ & $9 \pm 0.5$ & $8 \pm 1.0$ & $4 \pm 0.7$ & $0 \pm 0$ \\
\hline $\begin{array}{l}\text { In vitro inhibition of } \boldsymbol{R} \text {, } \\
\text { solanacearum }\left(0.5 \times 10^{9}\right. \\
\mathrm{CFU} / \mathrm{ml}) * 2\end{array}$ & $5 \pm 0$ & $4 \pm 0.4$ & $3 \pm 0.6$ & $2 \pm 0.3$ & $0 \pm 0$ \\
\hline Wilt severity in clay soil ${ }^{3}$ & $28 \pm 14$ & $40 \pm 16$ & $24 \pm 13$ & $46 \pm 16$ & $80 \pm 13$ \\
\hline$\%$ decrease compared to PC & 65 & 50 & 70 & 42.5 & \\
\hline AUDPC in clay soil ${ }^{4}$ & $25 \pm 8$ & $26 \pm 11$ & $15 \pm 8$ & $36 \pm 8$ & $51 \pm 9$ \\
\hline$\%$ decrease compared to PC & 51 & 49 & 71 & 29 & \\
\hline Wilt severity in sandy soil ${ }^{5}$ & $98 \pm 2$ & $48 \pm 16$ & $44 \pm 13$ & $90 \pm 10$ & $100 \pm 0$ \\
\hline$\%$ decrease compared to PC & 2 & 52 & 56 & 10 & \\
\hline AUDPC in sandy soil ${ }^{6}$ & $56 \pm 6$ & $32 \pm 9$ & $24 \pm 8$ & $57 \pm 6$ & $46 \pm 6$ \\
\hline \% decrease compared to PC & 13 & 51 & 59 & 12 & \\
\hline
\end{tabular}

$* 0.5 \mathrm{mg}$ of methanolic algal extract

\section{Significant correlations:}

$\mathrm{a}, 4(-0.9, P=0.03),{ }^{\mathrm{a}, 5}(-0.81, P=0.1),{ }^{\mathrm{a}, 6}(-0.89, P=0.05), \quad \mathrm{b}, 1 \quad(+0.79, P=0.1), \mathrm{b}, 2(+0.84, P=0.08)$,

$c_{1}, 1(+0.84, P=0.08), c, 3(-0.94, P=0.03),{ }^{c, 4}(-0.78, P=0.1), \quad d, 5(-0.97, P=0.02), d, 6(-0.97, P=0.02)$

e,5(-0.97, $P=0.02),{ }^{e}, 6(-0.97, P=0.02), \quad f, 1(+0.85, P=0.07),{ }^{f, 2}(+0.86, P=0.07),{ }^{f, 3}(-0.82, P=0.09)$,

i,4 $(-0.91, P=0.05), \mathrm{i}, 5(-0.84, P=0.08), \mathrm{i}, 6(-0.925, P=0.08), \mathrm{h}, 5(-0.94, P=0.03), \mathrm{h}, 6(-0.91, P=0.04)$,

g,3 $(-0.84, P=0.08),{ }^{9,4}(-0.98, P=0.01),{ }^{9,5}(-0.79, P=0.1)$,

a, $g(+0.98, P=0.01), \mathrm{a}, \mathrm{i}(+0.9, P=0.05), \quad \mathrm{b}, \mathrm{c}(+0.92, P=0.04), \mathrm{b}, \mathrm{f}(+0.99, P=0.005)$,

c, g $(+0.79, P=0.1), c, f(+0.99, P=0.01)$, d, e $(+0.99, P=0.07), \mathrm{d}$ h $(+0.996, P=0.002), \mathrm{d}$ I $(+0.82, P=0.09)$,

e, h $(+0.98, P=0.008),{ }^{e}$ i $(+0.9, P=0.048)$. 


\section{DISCUSSION}

Marine macroalgae are considered to be a rich source of bioactive compounds showing great antimicrobial activities. In the present study, maximum inhibition zones were recorded for $U$. lactuca followed by $A$. spicifera and $C$. racemosa while $S$. dentifolium showed the least inhibition zone. The antibacterial activity of $S$. latifolium against $R$. solanacearum and $P$. carotovora was previously addressed by Ibraheem et al., (2017), where they also reported that, the most effective antibacterial activity resided in the methanolic extract. In the present work, some phenolic compounds are directly correlated with antibacterial activity in vitro such as gallic and coumaric acids while others correlated with disease suppression such as hydrxybenzoic, chlorogenic, vanillic, salicylic and freulic aids. Alves et al., (2013) showed that 2,4dihydroxybenzoic, vanillic and $\mathrm{p}$-coumaric acids had antibacterial activity (MIC $=1$ $\mathrm{mg} / \mathrm{ml}$ ) against $E$. coli. Phenolic compounds are known for their antioxidant and bactericidal potential and marine macroalgal products are known for being rich in phenolic compounds (Machu et al., 2015, Hamed et al., 2018).The antibacterial properties of the gallic acid, extracted from pomegranate and acacia fruit, against $R$. solanacearum was proven by Farag et al., (2015). In this study, cinammic acid showed negative correlation with disease incidence. Cinammic acid is known to participate in the formation of lignin which may explain this correlation (Guzman, 2014). The disease suppressive effect of phenolic acids may be attributed to enhancing the formation of lignin (Hahlborck and Sheel, 1989) and inhibit some microorganisms which are resistant to conventional antibiotic (Alves et al., 2013).

The disease incidence was higher in sandy soil as compared to clay soil. The lower effect of different algal extracts in sandy soil may be attributed to the excess reactive oxygen species (ROS) produced in plants which was probably less than the amount of available antioxidants. Most algal extracts were more effective in clay soil as compared to sandy soil with the exception of $C$. racemosa, which was more effective in sandy soil. The disease suppressive effect of SWEs was correlated partially to enhancing nutrient uptake by plant (Farag et al., 2017). Reactive oxygen species (ROS) is one of the most significant signals of pathogenesis (Torres et al., 2006). The excess ROS is controlled by a complex defense mechanism of antioxidants by the living organism, when the amount of ROS exceeds the available antioxidant, the organism become diseased (Machu et al., 2015). The total determined phenolic compounds was high in A. spicifera and low for $S$. dentifolium which may explain the highest potential of disease suppression associated with $A$. spicifera as compared to $S$. dentifolium. Positive correlation between hydroxybenzoic class of the phenolic compounds (such as gallic acid and 4-hydroxybenzoic) and antioxidant capacity of water soluble compounds was proven by Machu et al., (2015). Hydroxybenzoic acid is an essential component of 
building lignin (Machu et al., 2015) which may explain its role in plant defense against plant pathogens. Both hydroxybenzoic and gallic phenolic compounds showed the highest proportion in $U$. lactuca and $A$. spicifera and were the lowest in $S$. dentifolium which may in part explain the varied effect of the different algal extracts on disease suppression. Vanillin is produced from ferulic acid (Plaggenborg et al., 2006) which could suggest the relation between ferulic and vanilic acid in the analyzed phenolic compound content of different extracts.

\section{REFERENCES}

1. Alves, M.J., I.C.F.R. Ferreira, H.J.C. Froufe, R.M.V. Abreu, A. Martins and M. Pintado 2013. Antimicrobial activity of phenolic compounds identified in wild mushrooms, SAR analysis and docking studies. Journal of Applied Microbiology, 115: 346-357.

2. Anonymous. 1998. Council Directive 98/57/EC of 20 July 1998 on the control of Ralstonia solanacearum (Smith) Yabuuchi et al. Publication 97/647/EC, Official Journal European Communities L235: 8-39.

3. Elhalag, K.M., N.A.S. Messiha, H.M. Emara and S.A. Abdallah 2016. Evaluation of antibacterial activity of Stenotrophomonas maltophilia against Ralstonia solanacearum under different application conditions. Journal of Applied microbiology, 120: 1629-1645.

4. Farag, N.S., W.E. Eweda, M.I. Mostafa and N.M. Balabel 2004. Preliminary observations on the bacteriology and pathology of Ralstonia solanacearum. Egypt Journal of Agricultural Research, 82: 1519-1523

5. Farag, M.A., D.A. Al-Mahdy, R. Salah El Dine, S. Fahmy , A. Yassin , A. Porzel and W. Brandt 2015. Structure-Activity Relationships of Antimicrobial Gallic Acid Derivatives from Pomegranate and Acacia Fruit Extracts against Potato Bacterial Wilt Pathogen. Chemistry \& Biodiversity, 12: 955-962

6. Farag, S.M.A., K.M.A. Elhalag, M.H. Hagag, A.M. Khairy, H.M. Ibrahim, M.T. Saker and N.A.S. Messiha. 2017. Potato bacterial wilt suppression and plant health improvement after application of different antioxidants. Journal of Phytopathology 165:522-537.

7. Guzman, J.D. 2014. Natural Cinnamic Acids, Synthetic Derivatives and Hybrids with Antimicrobial Activity. Molecules, 19: 19292-19349

8. Hamed, S.M., A.A. Abd El-Rhman, N. Abdel-Raouf, I.B. Ibraheem 2018. Role of marine macroalgae in plant protection $\&$ improvement for sustainable agriculture technology. Beni-Suef University Journal of Basic and Applied Sciences, 7: 104.

9. Hahlbrock, K. and D. Scheel 1989. Physiology and molecular biology of phenylpropanoid metabolism. Annual Review of Plant Physiology and Plant Molecular Biology, 40: 347-369. 
10. Hellio, C., D. de La Broise, L. Dufossé, Y. Le Gal and N. Bourgougnon 2001. Inhibition of marine bacteria by extracts of macroalgae: potential use for environmentally friendly antifouling paints. Marine Environmental Research, 52: 231-247.

11. Ibraheem, I.B.M., S.M. Hamed, A.A. Abdelrhman, F.M. Farag and N. Abdel-Raouf 2017. Antimicrobial activities of some brown macroalgae against some soil borne plant pathogens and in vivo management of Solanum melongena root diseases. Australian Journal of Basic and Applied Sciences, 11(5): 157-168

12. Janse, J.D. 1988. A detection method for Pseudomonas solanacearum in symptomless potato tubers and some data on its sensitivity and specificity. Bulletin OEPP/EPPO Bulletin, 18: 343-351.

13. Machu, L., L. Misurcova, J.V. Ambrozova, J. Orsavova, J. Mlcek, J. Sochor and T. Jurikova 2015. Phenolic Content and Antioxidant Capacity in Algal Food Products. Molecules, 20, 1118-1133.

14. Majeed, A., Z. Muhammad, S. Islam, Z. Ullah, R. Ullah 2017. Cyanobacterial Application as Bio-fertilizers in Rice Fields: Role in Growth Promotion and Crop Productivity. PSM Microbiology 2(2): 47-50.

15. Matanjun, P., S. Mohamed, N.M. Mustapha, K. Muhammad, C.H. Ming 2008. Antioxidant activities and phenolics content of eight species of seaweeds from north Borneo. Journal of Applied Phycology, 20: 367-373.

16. Messiha, N.A.S. 2006. Bacterial wilt of potato (Ralstonia solanacearum race 3, biovar2): Disease management, pathogen survival and possible eradication. PhD thesis Wageningen University, The Netherlands.

17. Messiha, N.A.S., A.H.C. van Bruggen, A.D. van Diepeningen, O.J. de Vos, A.J. Termorshuizen, N.N.A. Tjou-Tam-Sin and J.D. Janse (2007a). Potato brown rot incidence and severity under different management and amendment regimes in different soil types. European Journal of Plant Pathology, 119:367-381.

18. Messiha, N.A.S., A.D. van Diepeningen, M. Wenneker, A.A.R. van Beuningen, J.D. Janse, T.G.C. Coenen, A.J. Termorshuizen, A.H.C. van Bruggen and W.J. Blok (2007b) Biological Soil Disinfestation, a new control method for potato brown rot, caused by Ralstonia solanacearum race 3 biovar 2. European Journal of Plant Pathology, 117:403-415.

19. Mikhail, M.S., B.A. Hussein, N.A.S. Messiha, K.M.M. Morsy and M.M.Youssef 2016. Using of Cyanobacteria in controlling potato brown rot disease. International Journal of Scientific \& Engineering Research, 7: 274-281. 
20. Mišurcová, L. 2011. Chemical composition of seaweeds. In Handbook of Marine Macroalgae: Biotechnology and Applied Phycology, Kim, S.-K., Ed.; John Wiley \& Sons: Chichester, UK; pp. 173-192.

21. Plaggenborg, R., J. Overhage, A. Loos, J.A.C. Archer, P. Lessard, A.J. Sinskey, A. Steinbuchel, H. Priefert 2006. Potential of Rhodococcus strains for biotechnological vanillin production from ferulic acid and eugenol. Appl Microbiol Biotechnol 72:745755.

22. Schönfeld, J., A. Gelsomino, L.S. van Overbeek, A. Gorissen, K. Smalla and J.D. van Elsas 2003. Effects of compost addition and simulated solarisation on the fate of Ralstonia solanacearum biovar 2 and indigenous bacteria in soil. FEMS Microbiololgy Ecology, 43: 63-74

23. Stevens, L.H., P.S. van der Zouwen, C.A.M. van Tongeren, P. Kastelein and J. van Beckhoven 2018. Survival of Ralstonia solanacearum and Ralstonia pseudosolanacearum in drain water. Bulletin OEPP/EPPO Bulletin, 48 (1), 97-104

24. Torres, M.A., J.D. Jones and J.L. Dangl 2006. Reactive oxygen species (Handling editor: Yong-Biao Xue) signaling in response to pathogens. Plant Physiology 141: 373-378.

25. Winstead, N.N. and A. Kelman 1952. Inoculation techniques for evaluating resistance to Pseudomonas solanacearum. Phytopathology: 42:628-634.

26. Yan, J. 1993. Influence of plant growth regulators on turf grass polar Lipid, tolerance to drought and saline stresses and nutrient efficiency. Dissertation, CSES, Virginia Tech.

27. Zhang, X., E.H. Ervin and R.E. Schmidt 2003. Physiological effects liquid applications of a seaweed extract and a humic acid on creeping bentgrass. Journal of the American Society for Horticultural Science, 128(4), 492-496.

28. Zhang, Q., J. Zhang, J. Shen, A. Silva, D.A. Dennis and C.J. Barrow 2006. Simple 96-well microplate method for estimation of total polyphenol content in seaweeds. Journal of Applied Ecology, 18: 445-450. 


\section{تثبيط مرض الأبول البكتيرى باستخدام بعض مستخلصات الطحالب

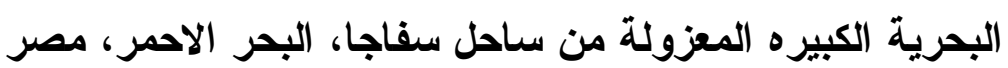

\section{سهام موسى محمد حامد و نيفين مسيحه}

$$
\begin{aligned}
& \text { 1. قسم الميكروبيولوجيا في التربة ، معهد بحوث التربة والمباه والبيئة ، مركز البحوث الزراعية }
\end{aligned}
$$

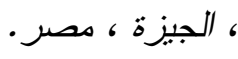

$$
\begin{aligned}
& \text { 2. قسم أمر اض النبات البكتبرية ، معهد بحوث أمراض النبات ، مركز البحوث الزراعية ، } \\
& \text { القاهرة ، مصر مر مصن }
\end{aligned}
$$

تعد الطحالب البحرية مصدر ممتاز للمركبات النشطة بيولوجيا. من بين 8 أنو اع مختلفة من

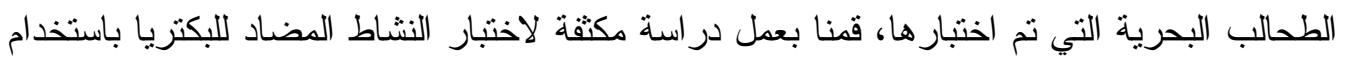

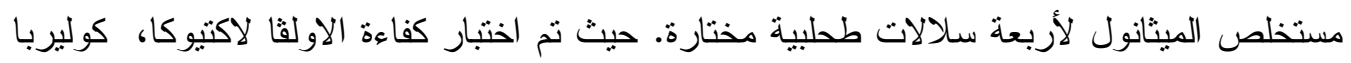

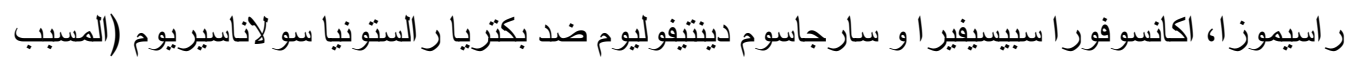
الرئيسى لمرض الذبول البكتيرى) ـ اظهر الفحص المختبرى ان الاولفا لاكتيوكا هى الاعلى فى النشاط

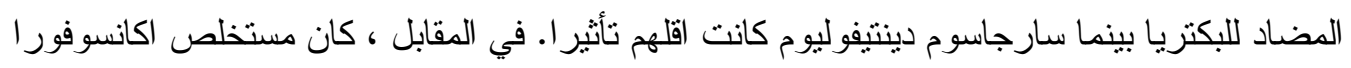

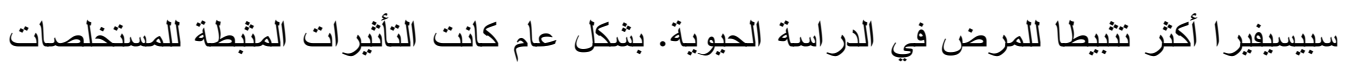

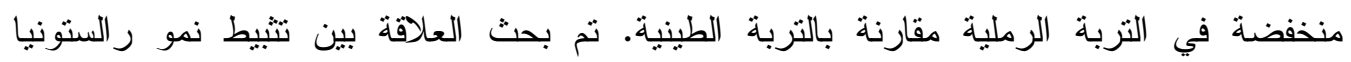
سو لاناسيريوم ، تثبيط مرض الذبول و محتوى المركبات الفينولية فى مستخلصات الطحالب. و أظهرت

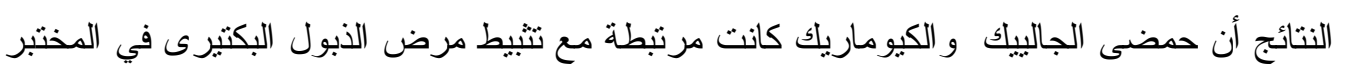

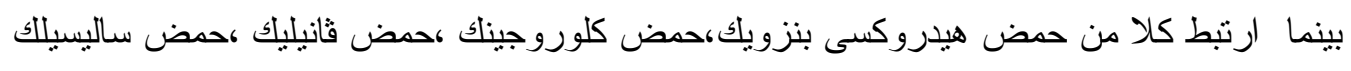
حمض الفيلورك مع تنبيط المرض في الظروف الحيوية خلال تجربة الصوبة ـ ـوعليه، يمكن استخدام مستخلصات الطحالب البحرية، كمضاد قوي للبكتريا و للأكسدة في النبات، كجزء من فئ البرنامج المتكامل للتحكم في الأمر اض النباتية. هناك حاجة لمزيد من البحث حوكل امكانية و جدوى التطبيق. 
